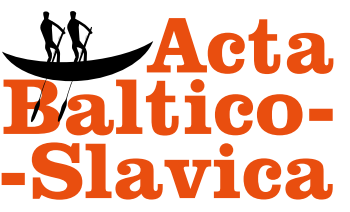

Acta Baltico-Slavica, 40

Warszawa 2016

DOI: $10.11649 /$ abs.2016.001

\title{
Elżbieta Smułkowa
}

Uniwersytet Warszawski

Warszawa

\section{Rozliczenie z Brasławszczyzną}

Dwutomowa publikacja Brasławszczyzna. Pamięć i współczesność (red. Smułkowa, 2009a, 2011) ${ }^{1}$ otrzymała kilka bardzo pozytywnych recenzji (Цыхун, 2011; Głuszkowski, 2012; Karaś, 2011; Толстая, 2012; Zielińska, 2011, 2013a) i wzmianek prasowych w Polsce i na Białorusi. Artykuł ten ma być wyrazem wdzięczności autorów monografii za uważne zapoznanie się recenzentów $\mathrm{z}$ ich tekstami, za wydobycie i podkreślenie zalet metodologicznych, teoretycznych i materiałowych pracy oraz ukazanie pewnych jej niedoróbek, czy nawet wyjątkowo błędów, jak w przypadku potraktowania niektórych wyrazów słowiańskich jako lituanizmów (Толстая, 2012, ss. 193-194). Dla mnie jako inicjatora, współautora i redaktora projektu jest to okazja ponownego nań spojrzenia z pewnej perspektywy czasowej; możliwość odpowiedzi recenzentom i pokazania, co można by było zrobić lepiej. Jednym słowem podejmuję próbę rozliczenia się z Brasławszczyzną - taką, jaką poznaliśmy na przełomie wieków, taką, jaka została ukazana w naszej zbiorowej publikacji, i jaką zachowali w pamięci nasi rozmówcy (por. rozdział Świadectwo mieszkańców w I tomie).

Hienadź Cychun w swojej recenzji szczególnie podkreśla wartość zastosowanego sposobu przedstawienia w słowniku materiału leksykalnego niezależnie od jego pochodzenia, cytując w białoruskim tłumaczeniu nasze sformułowanie z XVII strony wstępu:

1 Publikacja współfinansowana przez Fundację Lanckorońskich i Instytut Badań Interdyscyplinarnych „Artes Liberales”.

This is an Open Access article distributed under the terms of the Creative Commons Attribution 3.0 PL License (creativecommons.org/licenses/by/3.0/pl/), which permits redistribution, commercial and non-commercial, provided that the article is properly cited. (c) The Author(s) 2016. 
Гэта слоўнік «мовы пагранічча» - спроба прадэманстраваць узаемнае пранікненне дзьвюх, а нават трох моў, спроба фіксацыі і прадстаўлення працэсу іх інтэграцыі, а не апісанне кожнай лексічнай сістэмы асобна, як гэта практыкавалася дагэтуль. Такі спосаб сапраўды дазваляе вызначыць статус кожнай з моў ва ўзаемадзеянні ${ }^{2}$ (Цыхун, 2011, s. 181).

I popiera powyższe swoje sformułowanie ciekawym przykładem z rejestru tematycznego, pokazując, że po stronie polskiej prawie brak zapisów nazw niedorosłych zwierząt i ptaków, podczas gdy po białoruskiej jest ich bardzo dużo, np.: kaz"l'ata, kaz"l'onak, vaučańaty, barsučaty, v'ožyčk'i, s'ovuška, kukušonak, šćlygłačk'i, bac'ińata. Podobnie jest w przypadku różnego typu ekspresywów, np. wśród ekspresywnych czasowników mówienia: g'iv'ag'ac", z"iuc'i, kałd'ekajec", gardečuc", z"ardec"iš i inne, co może świadczyć o zachowaniu pierwotnej podstawy mowy prostej, utworzonej na bałtyckim substracie i wtórnym charakterze polszczyzny kresowej.

Recenzent zwraca uwagę na to, że dyferencjalny słownik wyrazów oznaczonych w rejestrze gwiazdką $\left.{ }^{*}\right)$ ma szczególne znaczenie, ponieważ zamieszcza obok neologizmów będących rezultatem kontaktu językowego (np. urodzimka urodzona w danej wsi'), zachowane na peryferii białoruskie archaizmy dialektalne, jak np. bahatka 'dmuchawiec' związana $\mathrm{z}$ * bogz 'доля’. Pomaga nam też zetymologizować leksem wejsło w zwrocie zostawić na wejsło 'na rozpłodek' jako lituanizm (lit. veisle 'rasa').

Podsumowując, Autor wyraża pogląd, że największym osiągnięciem autorek Słownika brasławskiego jest podejście do mowy na Brasławszczyźnie w perspektywie wielojęzyczności i związków międzykulturowych, co odpowiada postulatowi Baudouina de Courtenay, sformułowanemu przy opracowaniu gwar słoweńskich we Włoszech.

Можна толькі выказаць спадзяванне, што такі падыход да даследавання мовы пагранічча будзе прыняты іншымі даследчыкамі так званых кантактных зон у Беларусі і за яе межамі ${ }^{3}$ (Цыхун, 2011, s. 182).

\section{Z recenzji Swietłany M. Tołstoj:}

Несмотря на некоторые мелкие недочеты (в основном технического характера), рецензируемый труд представляет исключительную ценность и в теоретическом, и в методическом, и в практическом отношении. Впервые с такой полнотой и с ориентацией на специальную цель - отражение конвергентных процессов в условиях многоязычия - удалось собрать в полевых условиях и систематизировать столь значительный корпус лексики говоров пограничья на территории Браславского

2 "Jest to słownik «mowy pogranicza», próba pokazania jak przenikają się dwa, a nawet trzy języki, próba uchwycenia i przedstawienia procesu ich integracji, a nie opis każdego systemu leksykalnego z osobna, jak to było praktykowane dotychczas. Taki sposób faktycznie pozwala na wyznaczenie statusu każdego z języków będących w kontakcie”.

3 "Należy wyrazić nadzieję, że takie podejście do badania języka pogranicza zostanie podjęte przez innych badaczy tzw. obszarów kontaktowych (zon) na Białorusi i poza jej granicami”. 
района Белоруссии, и записать огромный массив текстов, демонстрирующих современное состояние конвергентных процессов в этом регионе. Примененная авторами методика сбора и обработки полевого материала, принципы его интегрального лексикографического представления послужат примером для многих других исследователей языковых и этнокультурных контактов на территориях пограничий (хотя каждое пограничье имеет свои характерные черты), а собранный материал станет важным источником для дальнейшего изучения языковой и культурной ситуации балто-славянского пограничья. Конечно, остается еще не мало вопросов, требующих своего столь же основательного изучения, напр., описание тех сфер лексики, которые остались неохваченными данным исследованием, таких, как ономастика, некоторые группы абстрактной лексики, многие разряды глаголов, и характерных для этих сфер интеграционных процессов, вопросы этнолигвистического характера, сопоставление картин мира представителей разных этнических и языковых групп и др. (эти вопросы лишь частично затронуты в рецензируемым труде). Но все дальнейшие исследователи этого региона уже не смогут обойтись без обращения к этому фундаментальному труду, созданному совместными усилиями польских и белорусских диалектологов и изданному в Варшаве (Толстая, 2012, s. 198).

Halina Karaś omawiając polską współczesną leksykografię gwarową, wymienia Słownik brasławski w grupie słowników naukowych z przełomu XX i XXI w., podkreśla, że uwzględnia się w nich „specyfikę środowiska wielokulturowego i wielojęzycznego" (Karaś, 2011, ss. 118, 122). Bliższemu omówieniu poddaje słownik w rozdziale V.14. Wybrane słowniki gwar kresowych i gwar przesiedleńców ze Wschodu (Karaś, 2011, ss. 319-323). Po przedstawieniu koncepcji układu materiału leksykalnego Autorka pisze:

Słownik uwzględnia perspektywę mówiących, ich kompetencję językową, pokazuje więc, jak mieszkańcy rejonu brasławskiego rozgraniczają dwa języki: polski i prosty (gwara białoruska), jak się nimi posługują. Zastosowana metoda pozwala na ukazanie całości leksyki, wszystkiego co funkcjonuje w ich języku/językach dzięki zastosowaniu rejestru tematycznego, który zawiera zarówno wyrazy wspólne z językiem ogólnym w używanej przez nich odmianie polszczyzny z językiem białoruskim w ich mowie prostej, jak i wyrazy specyficzne, charakterystyczne dla tych odmian lokalnych. Dzięki temu zabiegowi jest to pełny słownik mieszkańców Brasławszczyzny (Karaś, 2011, s. 322).

Dodałabym od siebie, że w sensie typologicznym nasz słownik jest niewątpliwie bliższy słownikowi pełnemu niż dyferencjalnemu. Trudno go jednak nazwać całkowicie pełnym ze względu na brak niektórych rodzajów słownictwa, jak np. onomastycznego, na co zwróciła uwagę Swietłana Tołstaja. Dziękuję recenzentce za wnikliwą i wyczerpującą prezentację Słownictwa dwujęzycznych mieszkańców rejonu (Słownika brasławskiego) i pozwalam sobie poniżej zacytować jeszcze jej wnioski:

Zastosowana metoda obocznej prezentacji słownictwa genetycznie różnojęzycznego (tu polskiego i białoruskiego z nakładającym się rosyjskim [oraz występującymi w nich 
lituanizmami - E.S.] jest interesującym sposobem ukazania stanu zmieszania regionalnych systemów językowych, polskiego i białoruskiego. Ukazuje też stan świadomości rozmówców co do przynależności używanego przez nich słownictwa (uważanego za polskie lub za białoruskie). Krótkie cytaty oraz stałe związki wyrazowe podawane w części tematycznej ilustrują użycie słów w kontekście, pozwalają często na określenie ich łączliwości leksykalnej czy składniowej. Istotne jest także przytaczanie form gramatycznych cytowanych wyrazów podstawowych ze względu na liczne przemieszania międzyjęzykowe, obserwowane w formach zależnych. Dla wykorzystania materiału leksykalnego zawartego w słowniku do dalszych badań bardzo ważnym rozwiązaniem metodologicznym jest lokalizacja i chronologizacja wszystkich zapisów (skrót zbadanych wsi i rok zapisu). Pozwala to na trafną ocenę sytuacji językowej i stanu tejże leksyki. Innym bardzo dobrym rozwiązaniem jest opis wyrazów sprawiających trudności w rozumieniu, oznaczonych gwiazdką w słowniku tematycznym (np. archaizmów, leksemów wieloznacznych, regionalizmów semantycznych i wyrazowych czy wyrazów powstałych okazjonalnie w wyniku interferencji), w słowniku alfabetycznym opracowanym według tradycyjnych zasad leksykografii gwarowej. Tak pomyślany i opracowany słownik języka bilingwalnych (czy raczej polilingwalnych) mieszkańców rejonu brasławskiego stanowi novum w polskiej leksykografii i w literaturze lingwistycznej obszarów wielojęzycznych (Karaś, 2011, ss. 322-323).

W recenzji Michała Głuszkowskiego, wykształconego lingwisty i socjologa, autora m.in. wartościowej pracy Socjologia $w$ badaniach dwujęzyczności. Wykorzystanie teorii socjologicznych $w$ badaniach nad bilingwizmem, cenne dla mnie jest podkreślenie, że II rozdział naszej monografii: Charakterystyka socjolingwistyczna ma charakter socjolingwistyczny nie tylko z nazwy i rzeczywiście realizuje postulat interdyscyplinarnej analizy wielowymiarowych zjawisk społeczno-kulturowych oraz językowych.

Cieszymy się, że udało nam się wykonać to jedno z zasadniczych założeń naszej autorskiej współpracy i że zostało to przez specjalistę potwierdzone. Ważne dla mnie w tej recenzji jest także podkreślenie wartości mego przedstawienia przykładów konwergencji językowej na wszystkich poziomach struktury języka i jej teoretycznej interpretacji z wykorzystaniem „socjolingwistycznych” stwierdzeń Ferdynanda de Saussure'a, zawartych w Szkicach z językoznawstwa ogólnego, które, jak pisze M. Głuszkowski, w polskiej lingwistyce głównego nurtu bywają ignorowane, a jego teoria znana jest przede wszystkim z Kursu językoznawstwa ogólnego.

Krytykowana przez Autora recenzji pewna nierównomierność sposobu i objętości opisu współistniejących na Brasławszczyźnie języków była zamierzona, a w recenzji Anny Zielińskiej właśnie została uznana za określoną wartość. Chciałyśmy uniknąć wielokrotnie powtarzanego w druku przedstawiania cech polszczyzny północnokresowej, skupiając uwagę na tym, co dla regionu specyficzne, i podejmując próbę ujęcia typologicznego idiolektów. Z pokorą natomiast przyjmuję oczywiste uwagi o trudnościach wynikających z zastosowania kryterium językowego w prezentacji tekstów ciągłych. Niech się więc teksty same bronią, jako cenny materiał do dalszych badań. 
Przechodzę do omówienia obu recenzji Anny Zielińskiej, pisanych bezpośrednio po wydaniu każdego z obydwu tomów Brasławszczyzny. Recenzje te mają dla nas duże znaczenie, gdyż autorka zwróciła uwagę na sprawy teoretyczne, na których mi bardzo zależało, a także, zainteresowana badaniem podobnych problemów w regionie lubuskim (Zielińska, 2013b), wzorując się w pewnym sensie na nas, zadała sobie trud doprecyzowania niektórych naszych sformułowań, za co chciałabym wyraźnie podziękować. Dotyczy to przede wszystkim mego rozumienia pojęcia konwergencji językowej jako dalszego etapu interferencji i zwrócenia uwagi na wartość rozróżniania pojęć konwergencji i integracji języków przy badaniu społecznej wielojęzyczności w warunkach pograniczy językowych. We wcześniejszych etapach pracy zdarzało mi się używać tych terminów zamiennie, z czego się pod wpływem poglądu recenzentki wycofałam. Przedstawiam poniżej istotne fragmenty recenzji A. Zielińskiej pierwszego tomu Brasławszczyzny:

Koncepcja Brasławszczyzny łączy badania konkretnego, zapisanego w dużych ilościach materiału językowego (w postaci nagranych tekstów mówionych uzyskanych w trakcie badań terenowych) z językoznawczą refleksją teoretyczną. Problemem współczesnych badań terenowych, dialektologicznych i socjolingwistycznych jest często brak odniesień do teorii języka. Badacze terenowi koncentrują się na materiale, a teoretycy języka wolą sięgać do przykładów z języków standardowych. Nowatorstwo autorskiego Zespołu tego projektu polega na próbie przezwyciężenia tego podziału (Zielińska, 2013a, s. 604).

Na podstawie przemyśleń Elżbiety Smułkowej i innych lektur spróbuję teraz podsumować, jak powstaje konwergencja. Mieszkańcy Brasławszczyzny dysponują trzema lub dwoma systemami językowymi - schematami. Schematy nie mogą wchodzić ze sobą w relacje, ponieważ są tworami abstrakcyjnymi (systemami opozycji funkcjonalnych). Schemat jest pojęciem wewnątrzlingwistycznym. Granica języka - systemu to jego rozumienie, mówiący nie może naruszyć dystynktywnych opozycji, por. podrozdział Wymagania systemu i wymagania normy (Weinsberg, 1983, s. 119).

[...]

Systemy są realizowane w granicach normy. Norma to pojęcie zewnętrznojęzykowe. Jest ustalona przez społeczność językową. Mieszkańcy Brasławszczyzny mają swoją ustaloną społecznie normę, którą jest naprzemienne realizowanie trzech/dwóch systemów językowych w obrębie tekstów, zdań i mniejszych jednostek językowych. W tej społeczności "mieszanie" języków jest normą pozwalającą między innymi na rozpoznawanie swojego i obcego. Obcy to ten, który nie „miesza” trzech języków albo czyni to w inny sposób. Nie jestem pewna, czy ma sens rozgraniczanie normy i uzusu w przypadku tzw. normy obiektywnej, czyli nieskodyfikowanej (Odróżnienie normy obiektywnej i preskryptywnej, Linde-Usiekniewicz 2011). Jest to norma dotycząca sposobów mówienia, a więc pokrywająca się $\mathrm{z}$ uzusem. W normie jest wzajemne przenikanie cech językowych. Sporadycznie występujące w idiolektach można nazywać zgodnie z tradycją weinreichowską interferencjami (przepływający piasek!), te, które się powtarzają, stają się habitualne i przejmują je inni mówiący to konwergenty (osadzający się piasek). Zaakceptowane przez znaczną grupę 
mówiących stabilizują się i powodują zmianę w jednym ze schematów: na przykład w schemacie języka polskiego w sylabach nieakcentowanych doszło do neutralizacji opozycji między samogłoskami szeregu średniego a innymi szeregami (s. 115-116). [...] Mowa to realizacja trzech/dwóch systemów w granicach społecznej normy. Badacz ma dostęp do mowy tylko dzięki tekstom. Teksty to materializacja mowy (Zielińska, 2013a, s. 609).

Trzeba jeszcze zwrócić uwagę na nieporuszany wprawdzie w recenzji Anny Zielińskiej problem języka „dawcy” i „biorcy” przy konwergencji językowej, który pojawił się jednak w jej książce Mowa pogranicza... w wyniku nieporozumienia, jak sądzę. Autorka pisze tak:

W przykładach podanych przez Elżbietę Smułkową konwergencja jest jednostronna, język polski jest zawsze „językiem biorcą”, a języki, zwłaszcza rosyjski - „językami dawcami”. [...] Inne rozumienie konwergencji proponuje Sarah Thomason (Thomason, 2001, s. 89). W jej ujęciu konwergencja zakłada równy udział dwóch języków w zmianach (Zielińska, 2013b, s. 61).

Po tych słowach Autorka cytuje dłuższą wypowiedź S. Thomason zakończoną słowami: „Mówienie o konwergencji prowadzi do unikania wyznaczania języka dawcy i języka biorcy"4 (Zielińska, 2013b, s. 61).

Po czym A. Zielińska wyciąga słuszny wniosek:

Konwergencja w takim rozumieniu zakłada równorzędność, podobny rozwój języków, upodabnianie się prowadzące do powstawania wspólnych cech przez funkcjonowanie w podobnych lub tych samych warunkach (Zielińska, 2013b, s. 62).

Przeciwstawienie mego rzekomego poglądu opinii Sarah Thomason jest nieporozumieniem. Nigdzie nie formułowałam twierdzenia o jednokierunkowości w konwergencji. W artykule Sytuacja socjolingwistyczna i proces konwergencji języków na Brasławszczyźnie w świetle badań terenowych (1997-2007), recenzowanym przez A. Zielińską, przykładowo skupiłam uwagę na wyrazistych przykładach z tekstów traktowanych jako polskie, pod wieloma względami upodobnionych do lokalnych wschodniosłowiańskich. Brakiem z mojej strony okazało się to, że nie pokazałam

4 "Some specialists in language contact have argued for two other types of contact - induced effect on a linguistic system, CONVERGENCE and RELEXIFICATION. Convergence, at its simplest, would be any process through which two or more languages in contact become more like each other; but this very broad definition would make almost every contact induced change a case of convergence, and it's not what people usually mean by the term. In practice, convergence is discussed primarily in two contexts. One is a contact situation in which both (orall) languages change in ways that make them more similar. In this context, the point of talking about convergence is to emphasize the fact that the interference is mutual, not unidirectional, and the fact the resulting convergent structures have no single source; either they were already present, but less prominent, in both languages, or they resemble both languages in part but do not match either on completely. Talking about convergence in this context is a way of avoiding the inappropriate (for this particular situation) terms 'source language' and 'receiving language'” (Thomason, 2001, s. 89). 
cech tekstów białoruskich, które pochodzą z kontaktu z językiem polskim, rosyjskim i litewskim. Nie naraziłabym wówczas recenzentki na zaprezentowany wniosek. Inna rzecz, że teoretyczne założenie o równorzędności języków biorących udział $\mathrm{w}$ procesie konwergencji trzeba odnosić wyłącznie do zbliżonych, jeżeli nie takich samych, warunków ich rozwoju i zakresu wykorzystania. Tymczasem nasze badania prowadzone były w sytuacji radykalnie zmienionych stosunków zewnętrznojęzykowych między językiem polskim a gwarami białoruskimi w odniesieniu do przeszłości sprzed połowy XX w. Język polski pełniący funkcje języka urzędowego, a domowego tylko w niektórych rodzinach, przez wojnę i zmiany granic państwowych stracił status języka państwowego i znacznie ograniczył zakres użytkowania w rodzinach wskutek powojennej migracji ludności. Zmniejszył się też zakres używania gwar litewskich. Zwiększyło się natomiast niewspółmiernie w stosunku do przeszłości oddziaływanie języka rosyjskiego. W tych zmienionych warunkach funkcjonowania wielojęzyczności rzeczą naturalną okazuje się znacznie większe upodobnianie się języków o mniejszym zasięgu wykorzystania do pozostałych, bardziej funkcjonalnie obciążonych. Wynika $\mathrm{z}$ tego wniosek, że zjawisko konwergencji językowej może mieć różne etapy rozwojowe zależne od czynników zewnętrznojęzykowych.

Po podsumowaniu części teoretycznej opracowania recenzentka przechodzi do omówienia autorskich opisów odmian językowych używanych na Brasławszczyźnie, podkreślając:

Bardzo dobrze, że zespół autorski nie wypracował jednolitego schematu opisu dla wszystkich języków. Każdy język ma odmienną historię i status socjolingwistyczny: są to gwary autochtoniczne - białoruskie i litewskie, gwary przeniesione - rosyjskie staroobrzędowców oraz różne warianty socjalne i idiolekty polskie i rosyjskie [...]. Artykuł Inesy Kuryan Charakterystyka idiolektów języka polskiego spotkał się z moim szczególnym uznaniem, ponieważ nie przedstawia polszczyzny w konwencji opisu dialektologicznego. Język polski w rejonie brasławskim należy do obszaru polszczyzny wileńskiej wyznaczonego przez Halinę Turską. Pochodzenie tej polszczyzny, znane doskonale z prac Turskiej, w żaden sposób nie pozwala na nazwanie jej gwarą lub dialektem, ponieważ nie jest to język autochtoniczny. Metoda opisu dialektologicznego byłaby tu niewłaściwa. Autorka wyróżnia trzy warianty języka polskiego używanego na Brasławszczyźnie: 1) Polszczyzna ogólna, realizowana bardzo rzadko, 2) polszczyzna wileńska, którą posługują się nieliczni potomkowie stanu szlacheckiego, 3) polszczyzna „mieszana”, czyli najczęściej spotykany wariant języka polskiego. [...] Na wszystkich płaszczyznach języka tekst jest przesycony białorutenizmami, zwłaszcza składnia jest bliższa białoruskiemu niż polskiemu. W mojej opinii przedstawianie tekstów prezentujących różne warianty polszczyzny jest najlepszym sposobem opisywania polszczyzny północnokresowej, nie tylko na Brasławszczyźnie, ale też na całym terytorium jej występowania (Zielińska 2013a, ss. 609-610).

Jest w recenzji tego artykułu też słuszna krytyka odnoszenia miejscowej polszczyzny do normy ogólnopolskiej: „Ocenianie lokalnego wariantu polszczyzny w odniesieniu do normy ogólnopolskiej jest błędem metodologicznym” (Zielińska 
2013a, s. 610). Zgadzam się całkowicie z recenzentką i przykro mi, że jako redaktor książki dopuściłam do pozostawienia tak podstawowego błędu. Podobnie reaguję na zwrócenie uwagi na używane w artykule Olgi Guszczewej kwalifikatory lokalnie używanego języka rosyjskiego jako wymowa „staranna” - „niestaranna” zamiast „standardowa” - „niestandardowa” lub „ogólna” i „potoczna”.

Anna Zielińska w recenzji II tomu Brasławszczyzny. Słownictwo dwujęzycznych mieszkańców rejonu (Słownik brasławski) (Zielińska, 2011), w sposób precyzyjny odczytuje i interpretuje założenia metodyczne autorek słownika, mówiąc, że:

Koncepcja słownika jest wynikiem rozumienia pogranicza przez Elżbietę Smułkową, pogłębianego w jej kolejnych artykułach (m.in. Smułkowa 2002, 2003, 2005, 2007). Pogranicze traktowane jest jako specyficzny obszar, na którym dochodzi do szczególnego rodzaju kontaktu kultur (Zielińska, 2011, s. 278).

Dalej autorka recenzji przytacza moje definicje pogranicza, konstatując, że podobnie jak wskazał to już Uriel Weinreich, traktuję człowieka jako miejsce kontaktu językowego i przyjmuję antropologiczny punkt widzenia w badaniu kultury i języka na pograniczu.

Koncepcja słownika związana jest $\mathrm{z}$ antropologiczną metodą pracy w terenie, polegającą głównie na rozmowach i uważnym słuchaniu informatorów (Smułkowa, Engelking (red.) 2007). Zgodnie z podejściem antropologicznym badania prowadzone są z perspektywy „od wewnątrz", a badacz dąży do poznania rzeczywistości z punktu widzenia członków opisywanej grupy, poszukuje ich sposobów kategoryzacji świata. [...] Informacja o poczuciu posługiwania się mieszanym językiem stała się metodologicznym punktem wyjścia dla Autorek słownika. Wybór sposobu prezentacji leksyki używanej przez wielojęzyczną ludność rejonu brasławskiego podyktowany był potrzebą ukazania wysokiego stopnia przenikania się leksemów polskich, białoruskich, litewskich i rosyjskich. Wywiady z mieszkańcami Brasławszczyzny były prowadzone w różnych językach: po polsku, białorusku i rosyjsku. Badaczki zaobserwowały zjawisko przemieszania leksykalnego w ramach wypowiedzi, która w intencji rozmówcy miała być $w$ jednym języku. O wyborze leksemu decyduje stan kompetencji językowej w ramach wypowiadania się na podjęty temat. Informatorzy nie trzymają się kodu wybranego ze względu na partnera rozmowy (Smułkowa, 2009, s. X). Obserwacja Autorek jest bardzo ważna metodologicznie, ponieważ nawiązuje do koncepcji etnografii mówienia Della Hymesa, w której zachowania werbalne jednostki rozpatruje się w szerszym kontekście zachowań społecznych. Adekwatne wydaje się zastosowanie terminu kompetencja socjolingwistyczna (lub komunikatywna), czyli taka, która obejmuje nie tylko umiejętność tworzenia poprawnych gramatycznie zdań, ale też znajomość reguł ich użycia (Bokszański, Piotrowski, \& Ziółkowski, 1977, s. 75). Autorzy prac poświęconych wielojęzyczności przyjmują, że osoba wielojęzyczna nie dysponuje kilkoma oddzielnymi kompetencjami, których suma jest równa sumie języków, lecz jedną szeroką kompetencją, będącą ich syntezą (por. Lüdi \& Py, 1984, ss. 51-53). [...] Człowiek pogranicza kształtuje swoją kompetencję $\mathrm{w}$ trakcie rozmaitych interakcji w życiu społecznym i ma taką kompetencję jaka jej wystarcza do odgrywania swoich ról społecznych (por. Zielińska, 1996, ss. 124-125) (Zielińska, 2011, ss. 279-280). 
W powyższym zdaniu być może wkradł się błąd drukarski i warto by poprawić partię końcową na: „i ma taką kompetencję, jakiej wystarcza mu do odgrywania swoich ról społecznych".

Po ważnych sformułowaniach ogólnych dotyczących recenzowanej pracy Anna Zielińska przechodzi do prezentacji układu słownika i naszych zasad redakcyjnych, których tu nie będę powtarzać, ponieważ dokładnie przedstawione są w słowniku. Chciałabym natomiast podziękować recenzentce za zwrócenie uwagi na to, że:

słownik mowy pogranicza wpisuje się w koncepcję Leszka Bednarczuka istnienia wspólnoty komunikatywnej Wielkiego Księstwa Litewskiego. Badacz uważa, że na obszarze WKL wytworzyła się swoista wspólnota komunikatywna. Nie osiągnęła ona wprawdzie takiej spójności, jak na przykład liga bałkańska, ale wpłynęła na ukształtowanie wszystkich pozostających w kontakcie języków i dialektów (Bednarczuk, 1999, ss. 113-114) (Zielińska, 2011, ss. 282).

Dziękuję także za uwydatnienie w recenzji mego poglądu na to, jak w mowie pogranicza przejawiają się jego najważniejsze cechy społeczne (Smułkowa, 2007, ss. 8-9):

a) Unifikacja sposobu życia i zwyczajów, zacieranie symbolicznych granic między swoim a innym, bo przecież nie zawsze obcym, wyraża się w istnieniu słownictwa funkcjonalnie wspólnego.

b) Akceptacja pograniczności, otwarcie na inność w mowie pogranicza przekłada się na konwergencję i przełączanie kodów oraz nazywanie swojego języka mieszanym.

c) Sytuacyjność (wariantywność) i stopniowalność integracji kulturowej pociąga za sobą sytuacyjność w mowie pogranicza. Kompetencja socjolingwistyczna jest związana z sytuacją, w jakiej odbywa się rozmowa (interakcja). Występuje w niej stopniowalność i wariantywność interferencji.

W zakończeniu Anna Zielińska pisze:

Wyrażam nadzieję, że słownik mowy pogranicza stanie się inspiracją do podejmowania następnych odważnych prób opisów językoznawczych na płaszczyźnie parole. Materiał ujęty w hasła daje pełną informację nie tylko o leksemach użytych w rozmowach po polsku i po białorusku, ale też o ich kontekstach, formach gramatycznych i wariantach fonetycznych (również akcentologicznych). Stanowi cenne źródło do badań nad wielojęzycznością (Zielińska, 2011, s. 282).

Brasławszczyzna. Pamięć i wspótczesność w dwóch tomach jest nie tylko kompendium wiedzy o pewnym regionie, ale również metodologiczną propozycją opisu pogranicza i wielojęzyczności niezależnie od terenu geograficznego. Najważniejsze jest postawienie kilku teoretycznych pytań wynikających z empirycznej analizy materiału językowego. $\mathrm{W}$ mojej opinii ta publikacja jest najważniejszym w polskiej nauce dziełem dotyczącym badania pograniczy i kontaktów językowych (Zielińska, 2013a, s. 611).

Na tle powyższych opinii Państwa Recenzentów z tym większą pokorą i skruchą obserwuję z perspektywy czasu pewne niedoróbki i błędy techniczne w słowniku, 
z których kilka pragnę poniżej zasygnalizować, aby nie zaskakiwały użytkowników i mogły zostać łatwiej poprawione w ewentualnym drugim wydaniu pracy.

1. Jak wiadomo, podstawowy materiał leksykalny wraz z przykładami użycia poszczególnych leksemów i często zestawem ich form gramatycznych zawarty jest w części I słownika, zatytułowanej Rejestr tematyczny słownictwa. Do tego rejestru sporządzony jest, jako część II, Indeks alfabetyczny ograniczony do tak zwanych „haseł wywoławczych" dla wielu różnych leksemów współrdzennych. Część III stanowi słownik alfabetyczny trudniej zrozumiałych wyrazów opatrzonych w rejestrze tematycznym gwiazdką $\left.{ }^{*}\right)$.

Otóż jeden z częstszych niewykorygowanych błędów wiąże się z tą gwiazdką:

a) * jest w rejestrze - leksemu brakuje w słowniku, ponieważ uznałyśmy, że znaczenie w rejestrze tematycznym jest dostatecznie jasne, a nie skasowałyśmy gwiazdki w odpowiednich miejscach, np. s. 207 11.1.1. Części wozu: pšodek ${ }^{\star}$ itp.;

b) ${ }^{\star}$ jest w rejestrze - leksemu brakuje w słowniku, mimo że niewątpliwie powinien był się tam znaleźć, np. zašpl'intovac”* od špl'int 11.1.1.;

c) * zostaje umieszczona po całym zwrocie, a nie po leksemie, do którego się odnosi, np. 11.10.1. Czasowniki ruchu: w przykładzie za bal'šak'om autobus pšyxoz"i*, gdy chodzi o objaśnienie leksemu bal'š'ak.

2. Przy okazji sprawdzania miejsca znaku $\left(^{*}\right)$ i opracowania słownikowego leksemów nim opatrzonych doszłam do wniosku, że można było lepiej wyeksponować w części III wieloznaczność odnotowanych wyrazów tekstowych, nie ograniczając się tylko do oznakowanych $\left.{ }^{*}\right)$. Na przykład, w części III znalazło się hasło nóż zob. raz'ak 'część pługa'. Natomiast znaczenie częstych zapisów tego leksemu w wersji polskiej nuš i w białoruskiej noš jako 'nóż kuchenny' pozostaje dostępne tylko w części tematycznej XIV.1. Przygotowanie pokarmów.

3. Inny przykład: sprawdzam, czy w słowniku znajduje się leksem kosa w znaczeniu 'śledziona świni'. W słowniku alfabetycznym nie ma. Jest tam tylko kosa 'warkocz', wyraz opatrzony ${ }^{*}$ w indeksie i w rozdziale I Człowiek. Sprawdzam zapisy indeksowe kosa bez gwiazdki i okazuje się, że w rozdziale III. Hodowla w grupie 3.9.3. jest kosa // kas'a obok wariantów fonetycznych białoruskiego leksemu sielazionka 'śledziona'. Błąd polega na braku oznaczenia wyrazów kosa* i sielazionka* i odpowiedniego opracowania haseł w III części słownika - alfabetycznej.

4. I jeszcze jedna uwaga samokrytyczna. Wbrew założeniu, aby wszystkie trudniejsze do zrozumienia lub w jakiś sposób charakterystyczne dla miejscowego języka, wyrazy znajdujące się w tekstach ciągłych, przedstawionych w rozdziale Świadectwo mieszkańców w tomie I zostały wprowadzone do Słownika, niektórych z nich brakuje. Na przykład na stronie I-377 (wers 7 od dołu) znajduje się charakterystyczny zwrot 
pamięć już podwodzi (ros. 3 sg noдвoдum) 'zawodzi'; albo (I-379, w. 3 od góry) i nie możno było tam patrzyć $i$ wskrywać jego, chodziło o dokument wojskowy, którego nie wolno było otwierać (brus. yскрываць 'ts').

Podsumowując swoje „rozliczenie z Brasławszczyzną”, pragnę podkreślić, że nasz międzynarodowy zespół autorski włożył wiele wysiłku i dobrej woli, żeby poznać i właściwie zrozumieć fenomen życia aktualnej społeczności regionu, jej wzajemne uwarunkowania i stosunki, i przede wszystkim sposób międzygrupowej komunikacji. Uwzględniając, oczywiście, wszelkie przemiany historyczne w regionie.

Naszego obszernego dwutomowego wydawnictwa, łącznie 1462 strony, nie traktujemy jednak jako ostatniego słowa. Jest to rzetelnie zebrany i zaprezentowany, (niestety nie bez uchybień), materiał terenowy, osadzony w określonej interpretacji teoretycznej, który może służyć do dalszych badań, i to nie tylko językoznawcom. Sproblematyzowany bogaty korpus tekstów mówionych dostarcza wiele ciekawych informacji na tematy tożsamościowe, stosunki wyznaniowe i narodowościowe, przeżycia wojenne, deportacje, partyzantkę radziecką i grupy Armii Krajowej, stosunek władz niemieckich i radzieckich do Polaków, problematykę gospodarczą i społeczną itp. Teksty transkrybowane można odsłuchiwać na załączonej płycie dźwiękowej.

Chciałabym na podstawie omawianej publikacji wrócić jeszcze do problematyki konwergencji językowej i innych problemów języka na pograniczu. Ufam, że gdybym już nie zdołała tego zrobić, nasze świadectwo o ludziach i mowie pogranicza i jej użytkownikach, badane i opracowane niedługo po przełomowym okresie wielorakich przemian $w$ regionie, zostanie wykorzystane przez innych badaczy pogranicza białorusko-polsko-litewskiego.

\section{Bibliografia}

Bednarczuk, L. (1999). Stosunki językowe na ziemiach Wielkiego Księstwa Litewskiego. Kraków: Edukacja.

Bokszański, Z., Piotrowski, A., \& Ziółkowski, M. (1977). Socjologia języka. Warszawa: Wiedza Powszechna.

Engelking, A. (2008). Kim jest „człowiek pogranicza?” Uwagi o tożsamości z perspektywy badacza i z perspektywy podmiotu - przykład białoruski. W A. Engelking, E. Golachowska, \& A. Zielińska (Red.), Tożsamość - Język - Rodzina: Z badań na pograniczu słowiańsko-bałtyckim (ss. 247-266). Warszawa: Slawistyczny Ośrodek Wydawniczy. 
Głuszkowski, M. (2012). Brasławszczyzna. Pamięć i współczesność. Tom I. Historia regionu. Charakterystyka socjolingwistyczna. Świadectwo mieszkańców. Warszawa: Wydawnictwa Uniwersytetu Warszawskiego, 2011, ss. 659. Slavia Orientalis, 61(4), 546-551.

Karaś, H. (2011). Polska leksykografia gwarowa. Warszawa: Wydział Polonistyki Uniwersytetu Warszawskiego.

Linde-Usiekniewicz, J. (2011). O normach i systemach. W B. Pędzich \& D. Zdunkiewicz-Jedynak (Red.), Polskie dźwięki, polskie słowa, polska gramatyka (System - teksty - norma - kodyfikacja). Warszawa: Wydział Polonistyki Uniwersytetu Warszawskiego.

Lüdi, G., \& Py, B. (1984). Zweisprachig durch Migration: Einführung in die Erforschung der Mehrsprachigkeit am Beispiel Zuwanderergruppen in Neuenburg [Schweiz]. Tübingen: Niemeyer. (Romanistische Arbeitshefte, 24).

Smułkowa, E. (2002). Kształt współistnienia na polsko-białorusko-litewskim pograniczu językowym. W E. Smułkowa, Białoruś i pogranicza: Studia o języku i społeczeństwie (ss. 483-491). Warszawa: Uniwersytet Warszawski.

Smułkowa, E. (2003). Badanie pograniczy językowych - uwagi metodologiczne. W J. Sierociuk (Red.), Gwary dziś (T. 2: Regionalne słowniki i atlasy gwarowe). Poznań: Wydawnictwo Poznańskie Towarzystwa Przyjaciół Nauk.

Smułkowa, Е. (2005). Думаючы пра памежжа. Acta Albaruthenica. Навуковы 3борнік, 5, 26-30.

Smułkowa, E. (2007). Wokół pojęcia pogranicza: Wschodnie i zachodnie pogranicze w ujęciu porównawczym. W E. Smułkowa \& A. Engelking (Red.), Pogranicza Białorusi w perspektywie interdyscyplinarnej (ss. 5-14). Warszawa: DiG.

Smułkowa, E. (2009). Uwagi o słownictwie dwujęzycznych mieszkańców Brasławszczyzny i sposobie jego prezentacji. W E. Smułkowa (Red.), Brasławszczyzna: Pamięć i współczesność (T. 2: Słownictwo dwujęzycznych mieszkańców rejonu (Słownik brasławski), ss. IX-XVII). Warszawa: Wydawnictwa Uniwersytetu Warszawskiego.

Smułkowa, E. (Red.). (2009a). Brasławszczyzna: Pamięć i współczesność (T. 2: Słownictwo dwujęzycznych mieszkańców rejonu (Słownik brasławski)). Warszawa: Wydawnictwa Uniwersytetu Warszawskiego.

Smułkowa, E. (Red.). (2011). Brasławszczyzna: Pamięć i współczesność (T. 1: Historia regionu. Charakterystyka socjolingwistyczna. Świadectwo mieszkańców). Warszawa: Wydawnictwa Uniwersytetu Warszawskiego.

Thomason, S. (2001). Language contact. Edinburgh: University Press.

Weinsberg, A. (1983). Językoznawstwo ogólne. Warszawa: Państwowe Wydawnictwo Naukowe.

Zielińska, A. (1996). Wielojęzyczność staroobrzędowców mieszkających w Polsce. Warszawa: Slawistyczny Ośrodek Wydawniczy.

Zielińska, A. (2011). O koncepcji słownika pogranicza: Brasławszczyzna: Pamięć i współczesność, t. 2. Słownictwo dwujęzycznych mieszkańców rejonu (Słownik brasławski), red. nauk. Elżbieta Smułkowa, zespół autorski: Iryna Budźko, Olga Guszczewa, Helena Kazancewa, Elżbieta Smułkowa, konsultacja lituanistyczna Nijola Birgiel, Wydawnictwa Uniwersytetu Warszawskiego, Warszawa 2009. Acta Baltico-Slavica, 35, 277-283. http:// dx.doi.org/10.11649/abs.2011.020 
Zielińska, A. (2013a). Brasławszczyzna. Pamięć i współczesność, t. 1. Historia regionu, charakterystyka sosjolingwistyczna, świadectwo mieszkańców, pod red. nauk. Elżbiety Smułkowej, Instytut Badań Interdyscyplinarnych „Artes Liberales” Uniwersytetu Warszawskiego, Warszawa 2013, ss. 659. Acta Baltico-Slavica, 37, 601-612. http://dx.doi.org/10.11649/abs.2013.042

Zielińska, A. (2013b). Mowa pogranicza: Studium o językach i tożsamościach w regionie lubuskim. Warszawa: Slawistyczny Ośrodek Wydawniczy, Instytut Slawistyki Polskiej Akademii Nauk.

Толстая, С. М. (2012). Brasławszczyzna. Pamięć i współczesność. T. 1: Historia regionu. Charakterystyka socjolingwistyczna. Świadectwo mieszkańców, red. nauk. Elżbieta Smułkowa. Warszawa: Instytut Badań Interdyscyplinarnych „Artes Liberales” Uniwersytetu Waszawskiego, 2011, 659 ss., + 1 płyta CD; T. 2: Słownictwo dwujęzycznych mieszkańców rejonu (Słownik brasławski), red. nauk. Elżbieta Smułkowa, Warszawa: Wydawnictwa Uniwersytetu Warszawskiego, 2009, 765 ss. Rocznik Slawistyczny, 61, 190-198.

Цыхун, Г. (2011). Brasławszczyzna. Pamięć i współczesność. T. II: Słownictwo dwujęzycznych mieszkańców rejonu (Słownik brasławski). Беларуская лінгвістыка, (67), 179-182.

\section{Bibliography (Transliteration)}

Bednarczuk, L. (1999). Stosunki językowe na ziemiach Wielkiego Księstwa Litewskiego. Kraków: Edukacja.

Bokszański, Z., Piotrowski, A., \& Ziółkowski, M. (1977). Socjologia języka. Warszawa: Wiedza Powszechna.

Engelking, A. (2008). Kim jest „człowiek pogranicza?” Uwagi o tożsamości z perspektywy badacza i z perspektywy podmiotu - przykład białoruski. In A. Engelking, E. Golachowska, \& A. Zielińska (Eds.), Tożsamość - Język - Rodzina: Z badań na pograniczu słowiańsko-bałtyckim (pp. 247-266). Warszawa: Slawistyczny Ośrodek Wydawniczy.

Głuszkowski, M. (2012). Brasławszczyzna. Pamięć i współczesność. Tom I. Historia regionu. Charakterystyka socjolingwistyczna. Świadectwo mieszkańców. Warszawa: Wydawnictwa Uniwersytetu Warszawskiego, 2011, ss. 659. Slavia Orientalis, 61(4), 546-551.

Karaś, H. (2011). Polska leksykografia gwarowa. Warszawa: Wydział Polonistyki Uniwersytetu Warszawskiego.

Linde-Usiekniewicz, J. (2011). O normach i systemach. In B. Pędzich \& D. Zdunkiewicz-Jedynak (Eds.), Polskie dźwięki, polskie słowa, polska gramatyka (System - teksty - norma - kodyfikacja). Warszawa: Wydział Polonistyki Uniwersytetu Warszawskiego.

Lüdi, G., \& Py, B. (1984). Zweisprachig durch Migration: Einführung in die Erforschung der Mehrsprachigkeit am Beispiel Zuwanderergruppen in Neuenburg [Schweiz]. Tübingen: Niemeyer (Romanistische Arbeitshefte, 24).

Smułkowa, E. (2002). Kształt współistnienia na polsko-białorusko-litewskim pograniczu językowym. In E. Smułkowa, Białoruś i pogranicza: Studia o języku i społeczeństwie (pp. 483-491). Warszawa: Uniwersytet Warszawski. 
Smułkowa, E. (2003). Badanie pograniczy językowych - uwagi metodologiczne. In J. Sierociuk (Ed.), Gwary dziś (Vol. 2: Regionalne słowniki i atlasy gwarowe). Poznań: Wydawnictwo Poznańskie Towarzystwa Przyjaciół Nauk.

Smułkowa, E. (2005). Dumaiuchy pra pamezhzha. Acta Albaruthenica. Navukovy Zbornik, 5, 26-30.

Smułkowa, E. (2007). Wokół pojęcia pogranicza: Wschodnie i zachodnie pogranicze w ujęciu porównawczym. In E. Smułkowa \& A. Engelking (Eds.), Pogranicza Białorusi w perspektywie interdyscyplinarnej (pp. 5-14). Warszawa: DiG.

Smułkowa, E. (2009). Uwagi o słownictwie dwujęzycznych mieszkańców Brasławszczyzny i sposobie jego prezentacji. In E. Smułkowa (Ed.), Brasławszczyzna: Pamięć i współczesność (Vol. 2: Słownictwo dwujęzycznych mieszkańców rejonu (Słownik brasławski), pp. IX-XVII). Warszawa: Wydawnictwa Uniwersytetu Warszawskiego.

Smułkowa, E. (Ed.). (2009a). Brasławszczyzna: Pamięć i współczesność (Vol. 2: Słownictwo dwujęzycznych mieszkańców rejonu (Słownik brasławski)). Warszawa: Wydawnictwa Uniwersytetu Warszawskiego.

Smułkowa, E. (Ed.). (2011). Brasławszczyzna: pamięć i współczesność (Vol. 1: Historia regionu. Charakterystyka socjolingwistyczna. Świadectwo mieszkańców). Warszawa: Wydawnictwa Uniwersytetu Warszawskiego.

Thomason, S. (2001). Language contact. Edinburgh: University Press.

Tolstaia, S. M. (2012). Brasławszczyzna. Pamięć i współczesność. T. 1: Historia regionu. Charakterystyka socjolingwistyczna. Świadectwo mieszkańców, red. nauk. Elżbieta Smułkowa. Warszawa: Instytut Badań Interdyscyplinarnych „Artes Liberales” Uniwersytetu Waszawskiego, 2011, 659 ss., + 1 płyta CD; T. 2: Słownictwo dwujęzycznych mieszkańców rejonu (Słownik brasławski), red. nauk. Elżbieta Smułkowa, Warszawa: Wydawnictwa Uniwersytetu Warszawskiego, 2009, 765 ss. Rocznik Slawistyczny, 61, 190-198.

Tsykhun, H. (2011). Brasławszczyzna. Pamięć i współczesność. T. II: Słownictwo dwujęzycznych mieszkańców rejonu (Słownik brasławski). Belaruskaia linhvistyka, (67), 179-182.

Weinsberg, A. (1983). Językoznawstwo ogólne. Warszawa: Państwowe Wydawnictwo Naukowe.

Zielińska, A. (1996). Wielojęzyczność staroobrzędowców mieszkających w Polsce. Warszawa: Slawistyczny Ośrodek Wydawniczy.

Zielińska, A. (2011). O koncepcji słownika pogranicza: Brasławszczyzna: Pamięć i współczesność, t. 2. Słownictwo dwujęzycznych mieszkańców rejonu (Słownik brasławski), red. nauk. Elżbieta Smułkowa, zespół autorski: Iryna Budźko, Olga Guszczewa, Helena Kazancewa, Elżbieta Smułkowa, konsultacja lituanistyczna Nijola Birgiel, Wydawnictwa Uniwersytetu Warszawskiego, Warszawa 2009. Acta Baltico-Slavica, 35, 277-283. http://dx.doi.org/10.11649/abs.2011.020

Zielińska, A. (2013a). Brasławszczyzna. Pamięć i współczesność, t. 1. Historia regionu, charakterystyka sosjolingwistyczna, świadectwo mieszkańców, pod red. nauk. Elżbiety Smułkowej, Instytut Badań Interdyscyplinarnych „Artes Liberales” Uniwersytetu Warszawskiego, Warszawa 2013, ss. 659. Acta Baltico-Slavica, 37, 601-612. http://dx.doi.org/10.11649/abs.2013.042

Zielińska, A. (2013b). Mowa pogranicza: Studium o językach i tożsamościach w regionie lubuskim. Warszawa: Slawistyczny Ośrodek Wydawniczy, Instytut Slawistyki Polskiej Akademii Nauk. 


\section{Rozliczenie z Brasławszczyzną \\ Streszczenie}

Artykuł ma do spełnienia dwa cele. 1. Ma podziękować Recenzentom dwutomowej publikacji Brasławszczyzna pamięć $i$ współczesność za uważne zapoznanie się z zawartymi w niej tekstami i słownikiem, za wydobycie i podkreślenie zalet metodologicznych, teoretycznych i materiałowych pracy oraz ukazanie pewnych jej braków. 2. Stwarza mi możliwość, jako współautorce i redaktorce projektu, przeprowadzenia polemiki z niektórymi poglądami Recenzentów oraz ukazania z perspektywy czasowej, co można było zrobić lepiej.

Słowa kluczowe: socjolingwistyka; pogranicze językowe; konwergencja i dywergencja językowa; integracja językowa; tożsamość; kontakty językowe

\section{Material from the Braslav in Belarus}

\section{Abstract}

This article has two aims: 1 . to thank the reviewers of the two-volume publication Brasławszczyzna, memory and the present for their careful study of the texts and glossaries included in it, for eliciting and emphasizing methodological, theoretical and material merits, and revealing some of its shortcomings. 2. To open the opportunity for me, as the author and the editor of the project, to engage in polemics with some of the outlooks of the reviewers and to show, from time perspective, what could have been done better.

Keywords: sociolinguistics; language border; linguistic convergention and divergention; linguistic integration; identity; language contact

Correspondence: Dr hab. Elżbieta Smułkowa, professor emeritus, Warsaw University, Artes Liberales Department,

e-mail: esmu@al.uw.edu.pl

Support of the work: Field research and a publicated work (by a team of authors), Słownik brasławski (Braclav Dictionary), which the published article deals with, were partly financed by the Lanckoroński Foundation and the Institute for Interdisciplinarny Research "Artes Liberales," Warsaw University (i.e., a grant and statutory research).

Competing interests: The author is a member of the Scientific Board of this journal. 